\title{
Rapid Microbial Detection Model System in UHT Milk Products using Poly(L-Lactic Acid) (PLLA) Thin Film
}

(Sistem Pengesanan Mikrob Model Pantas di dalam Produk Susu UHT menggunakan Filem Nipis (PLLA) Poli (Asid L-Laktik))

\author{
NURUl HidAYAH YUSOF, NORRAKIAH ABDUllaH SANI, FARAH HANNAN ANUAR, \\ MOHD SUZEREN JAMIL \& SAIFUL IRWAN ZUBAIRI*
}

\begin{abstract}
Ultra-high temperature is a process that involves heating of milk to a very high temperature to produce sterile milk products. However, food poisoning due to consumption of UHT milk still happen in Malaysia. This study was done to develop a film that is made by poly(L-lactic acid) (PLLA) to detect the presence of microorganisms in UHT milk products. UHT milk that was used in this study was full cream milk. Contaminated milk that contained Bacillus cereus was made to conduct a model system on the relationship between colony forming unit of microorganisms and contact angle. Contaminated milk was also used as a control sample to study the difference of milk properties between fresh and contaminated milk. Physicochemical analysis (Brix, colour, pH and contact angle) and microbiological analysis (total plate count) were done to UHT milk sample as soon as the packaging of the milk was unsealed. Analysis was done with 30 min time interval until $4 \mathrm{~h}$ and $30 \mathrm{~min}$ since the unsealing of packaging. The results showed that presence of microorganisms in UHT milk was detected after the milk product was unsealed and exposed to environment for $3 \mathrm{~h}$ and $30 \mathrm{~min}$. Contact angle resulted from the presence of microorganisms in UHT milk was 64.34 - $65.44^{\circ}$ with its colony forming unit, 2.1 - $3.9 \mathrm{cfu} / \mathrm{mL}$. Therefore, the potential usage of contact angle on PLLA thin film with respect to colony forming unit (cfu) in detecting the presence of microorganisms in UHT milk product was attained and well modelled.
\end{abstract}

Keywords: Contact angle; microorganisms; PLLA; spoilage indicator; UHT milk

\section{ABSTRAK}

Rawatan suhu ultra-tinggi merupakan proses yang melibatkan pemanasan susu kepada suhu yang amat tinggi bagi menghasilkan produk susu yang steril. Walau bagaimanapun, keracunan makanan akibat pengambilan susu UHT masih berlaku di Malaysia. Kajian ini dijalankan untuk membangunkan satu filem yang diperbuat daripada PLLA bagi mengesan kehadiran mikroorganisma dalam produk susu UHT. Susu UHT yang digunakan dalam kajian ini adalah susu krim penuh. Susu terkontaminasi yang mempunyai Bacillus cereus dihasilkan untuk menjalankan sistem model berkenaan hubungan antara unit pembentukan koloni mikroorganisma dengan sudut sentuh. Susu terkontaminasi juga digunakan sebagai sampel kawalan untuk mengkaji perbezaan sifat susu bagi susu segar dengan susu terkontaminasi. Analisis fizikokimia (Brix, warna dan sudut sentuh) dan analisis mikrobiologi (hitungan piring jumlah) dijalankan ke atas sampel susu UHT sebaik sahaja selepas pembungkusan susu dibuka. Analisis dijalankan dengan sela masa 30 min sehingga selepas empat jam dan 30 min pembungkusan dibuka. Keputusan menunjukkan kehadiran mikroorganisma dalam susu UHT dikesan selepas produk susu dibuka dan didedahkan kepada persekitaran selama tiga jam dan 30 min. Sudut sentuh yang dihasilkan akibat kehadiran mikroorganisma dalam produk susu UHT adalah 64.34 - $65.44^{\circ}$ dengan unit pembentukan koloni, 2.1 - 3.9 cfu/mL. Oleh yang demikian, potensi penggunaan sudut sentuh pada permukaan filem nipis PLLA terhadap unit pembentukan koloni dalam pengesanan mikroorganisma di dalam produk susu UHT telah diperoleh dan dimodelkan dengan berkesan.

Kata kunci: Indikasi kerosakan; mikroorganisma; PLLA; sudut sentuh; susu UHT

\section{INTRODUCTION}

According to Food Act 1983 (2015), ultra-high temperature (UHT) milk is milk that has been heated with temperature not less than $135^{\circ} \mathrm{C}$ for at least $2 \mathrm{~s}$ to make it commercially sterile. Tamime (2009) stated that contamination in UHT milk may happen due to two factors which are survival of heat resistant spore-forming bacteria and contamination after processing. In 2011, there were
97 food poisoning cases that was said due to UHT milk consumption from Program Susu 1Malaysia (PS1M). The milk was supplied by Dutch Lady Milk Industries Berhad (KKM 2012). Based on the laboratory test, there was $B$. cereus and its toxins in the milk (Yusmawati 2011). This is not surprising since Bacillus spp. is a pathogenic bacteria species that has been always related to contamination of UHT milk (Forschino et al. 1990; Luck et al. 1978; Skladal 
et al. 1993). Following this incidence, rapid detection is needed to prevent this problem in the future. Rapid detection should take less than $8 \mathrm{~h}$ (Cox et al. 1978) or enable to give results as soon as the test is done (Wang 2015). Moreover, rapid detection should be sensitive to ensure low count of microorganisms can be detected as well (Wang 2015). Poly(L-lactic acid) (PLLA) is a polymer that is commonly used to produce hydrophobic surfaces and has the potential in substrate cell growth and cell engineering (Sousa et al. 2011; Tsuji et al. 1988). Based on the past studies, bacterial strains were able to colonize on PLLA surface (Sousa et al. 2011). Hence, a study on rapid microbial detection in UHT milk using thin film PLLA was carried out to indicate food spoilage on UHT milk via rapid detection. In this study, simplified experimental setup was used to measure contact angle of UHT milk sample on PLLA thin film surfaces. In addition, contact angle measurement was used to study the wetting properties in solid (PLLA)/ liquid (milk) interaction whereby the components in microorganisms contributes to hydrophobicity of a cell surface thus plays an important role in the attachment to, or detachment from a surface (Che Johari et al. 2017; Krasowska \& Sigler 2014; Zubairi et al. 2016). For that reason, the presence of microorganisms in milk are somehow affected the surface tension of the milk and hence, may cause changes in its contact angle. This study had two objectives which were to study the profile of colony forming unit of microorganisms in UHT milk with different time interval and to study the relationship between wetting of thin film PLLA and colony forming unit of microorganisms.

\section{MATERIALS AND METHODS}

\section{MAKING OF CONTAMINATED UHT MILK}

MIC (Minimal Inhibitory Concentration) test (Coyle 2015) was used to make contaminated milk. Bacillus cereus strain used in this study was ATCC11778. One loop of the strain was added into tryptone soya broth (TSB) and incubated at $30^{\circ} \mathrm{C}$ for 18 to $24 \mathrm{~h}$. One loop of the bacterial culture was then streaked onto a nutrient agar to obtain a single colony of B. cereus. The single colony was then transferred into $10 \mathrm{~mL}$ of distilled water and compared with McFarland 0.5 standard. Microplate reading was also done on the B. cereus solution produced. This was to ensure that the colony forming unit of the bacterial solution was $1.5 \mathrm{cfu} /$ $\mathrm{mL}$ and hence, complied with the standard. To make the contaminated UHT milk, $1 \mathrm{~mL}$ of $B$. cereus solution was added into $9 \mathrm{~mL}$ of milk in test tube. The colony forming unit of B. cereus in milk would be $1.5 \mathrm{cfu} / \mathrm{mL}$.

\section{PREPARATION FOR FRESH UHT MILK PRIOR EXPERIMENT}

UHT milk sample used in this study was Dutch Lady's Pure Farm Full Cream Milk. The sample was bought on the day of experiment and kept it cool to ensure its freshness. As soon as the packaging of the milk was unsealed, the milk was transferred into five $100 \mathrm{~mL}$ Schott bottles with equal volume which represented five different analyses. The bottles were left uncapped for $4 \mathrm{~h}$ and $30 \mathrm{~min}$.

\section{FABRICATION OF THIN FILM PLLA}

The method used was adopted from a research by Ab Kadir et al. (2017, 2016) and Ili Afiqa (2017). 1 g of PLLA powder was weighed and added into $100 \mathrm{~mL}$ chloroform in a Schott bottle. The solution was then heated at $60^{\circ} \mathrm{C}$ and stirred by using magnetic stirrer with speed $100 \mathrm{rpm} /$ min until PLLA was fully dissolved. PLLA solution was then transferred into two Petri dishes with equal volume. Petri dishes were then left in desiccator overnight to let it dry. PLLA film was then formed and cut into micro slide size. The film was then glued onto micro slide.

\section{MODEL SYSTEM}

Serial dilution was done on contaminated milk, which was originally had $10^{7} \mathrm{cfu} / \mathrm{mL}$ of $B$. cereus until dilution $10^{1}$ to produce $1.5 \times 10^{1} \mathrm{cfu} / \mathrm{mL}$ colony counts of bacteria at the end of dilution. Contact angle of milk for each dilution was then measured by using Simplified Experimental Setup.

\section{PHYSICOCHEMICAL ANALYSIS}

Physicochemical analysis was done on both fresh and contaminated milk. Analyses that were done in this study were Brix, colour, $\mathrm{pH}$ and contact angle (Ramlan et al. 2018, 2017). Brix analysis was done by using Master refractometer (Master - 53 $\alpha$, Japan). Minolta Colorimeter, chromameter model (CR 400, Japan) was used for colour analysis by using Hunter Lab method. $\mathrm{pH}$ was measured using professional benchtop pH meter (BP3001). Calibration was done beforehand by measuring solution of pH4 (acid), pH7 (neutral) and pH9 (alkaline). Contact angle was measured by using Simplified Experimental Setup (Zubairi et al. 2015a, 2015b). All analyses were done with 30 min time interval which was as soon as the packaging of the milk was unsealed until the milk product was unsealed and exposed to environment for $4 \mathrm{~h}$ and $30 \mathrm{~min}$.

\section{MICROBIOLOGICAL ANALYSIS}

Microbiological analysis was done on fresh milk with 30 min time interval which was as soon as the packaging of the milk was unsealed until the milk product was unsealed and exposed to environment for $4 \mathrm{~h}$ and $30 \mathrm{~min}$. Total plate count was done using $3 \mathrm{M}^{\mathrm{TM}}$ Petrifilm ${ }^{\mathrm{TM}}$ Aerobic Count Plates. Serial dilution of milk was done until dilution of $10^{-2} .1 \mathrm{~mL}$ of milk for each dilution was inoculated on petrifilm and incubated at $30 \pm 1^{\circ} \mathrm{C}$ for $48 \mathrm{~h}$.

\section{STATISTICAL ANALYSIS}

Minitab version 17 (Minitab Inc., Sydney, Australia) and IBM SPSS Statistics version 23 (IBM Corporation, New York, United States) were used to analyse data. One-way ANOVA and Fischer test were done to compare the mean difference 
with confidence interval $95 \%(p<0.05)$. Coefficient of determination, $\mathrm{R}^{2}$ and Pearson correlation, $\mathrm{r}$ were done to measure the strength of relationship between variables in this study.

\section{RESULTS AND DISCUSSION}

Table 1 shows the result for model system. Model system was done to study the relationship between colony forming unit of microorganisms and contact angle. For the first three dilutions, $10^{7}$ to $10^{5}$, contact angle of milk was found to be decreased without any significant difference $(p>0.05)$. This shows that reduction of colony forming unit of microorganisms did not give a huge impact on contact angle of milk on PLLA film. Jones et al. (1996) stated that contact angle depends on bacterial attachment to substratum. Hence, reduction of bacterial attachment on PLLA from dilution until had happened due to reduction of colony forming unit of microorganisms. Less bacterial attachment caused the contact angle to decrease as well. As shown in Figure 1 and Table 2, regression analysis was showing a $\mathrm{R}^{2}$ of 0.74 in which about $74 \%$ of variance in contact angle was explained by serial dilution. Also, Pearson's $r$ for the correlation between contact angle and serial dilution was 0.80 which was very close to 1 . Thus,

TABLE 1. Contact angle for each dilution of contaminated milk

\begin{tabular}{cc}
\hline $\begin{array}{c}\text { Dilution/colony forming } \\
\text { unit }(\mathrm{cfu} / \mathrm{mL})\end{array}$ & $\begin{array}{c}\text { Contact angle, } \\
\vartheta\left({ }^{\circ}\right)\end{array}$ \\
\hline $10^{7}$ & $59.60 \pm 121^{\mathrm{bc}}$ \\
$10^{6}$ & $59.28 \pm 231^{\mathrm{bc}}$ \\
$10^{5}$ & $54.79 \pm 6.37^{\mathrm{c}}$ \\
$10^{4}$ & $62.60 \pm 1.07^{\mathrm{b}}$ \\
$10^{3}$ & $70.66 \pm 2.94^{\mathrm{a}}$ \\
$10^{2}$ & $71.71 \pm 4.23^{\mathrm{a}}$ \\
$10^{1}$ & $70.94 \pm 0.57^{\mathrm{a}}$ \\
$10^{0}$ & $72.05 \pm 0.86^{\mathrm{a}}$ \\
\hline
\end{tabular}

Results shown were means \pm S.D. in triplicate $(n=3){ }^{\text {a-c }}$ Mean with different letters indicate significant difference $(p<0.05)$

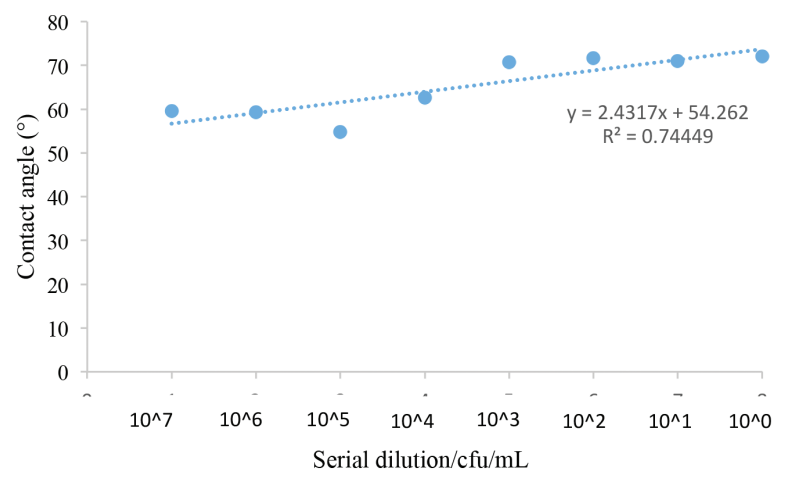

FIGURE 1. Contact angle for each dilution of contaminated milk. is the coefficient of determination which represents the proportion of the variance in contact angle was explained by serial dilution
TABLE 2. Coefficient of determination, $\mathrm{R}^{2}$ and Pearson correlation on strength of the linear relationship between serial dilution and contact angle

\begin{tabular}{lcc}
\hline & & Serial dilution \\
\hline Coefficient of determination, $\mathrm{R}^{2}$ & Contact angle & 0.75 \\
\hline Pearson correlation, $\mathrm{r}$ & Contact angle & 0.80 \\
\hline
\end{tabular}

there is a strong positive affiliation between contact angle and serial dilution.

Contact angle of UHT milk with 30 min time interval is shown in Table 3. There was significant difference between contact angle of control sample and fresh milk at the beginning of experiment, 0:00 $(p<0.05)$. However, at 1:30 and 2:30, no significant differences were detected between contact angle of control sample and fresh milk. Moreover, starting from 1:30, the contact angle of fresh milk began to exceed the contact angle of control sample which was contaminated milk. Hence, based on this analysis, probably UHT milk began to experience spoilage after $1 \mathrm{~h}$ and 30 min since its packaging was unsealed and exposed to environment. Microbiological analysis was done to ensure whether the spoilage was caused by the presence of microorganisms in milk sample.

TABLE 3. Contact angle of UHT milk with 30 min time interval

\begin{tabular}{cc}
\hline Time $(\mathrm{h})$ & Contact angle $\left(^{\circ}\right)$ \\
\hline $0: 00$ (control) & $59.60 \pm 1.21^{\mathrm{c}}$ \\
$0: 00$ & $53.19 \pm 0.88^{\mathrm{e}}$ \\
$0: 30$ & $53.27 \pm 1.11^{\mathrm{e}}$ \\
$1: 00$ & $56.12 \pm 1.26^{\mathrm{d}}$ \\
$1: 30$ & $60.49 \pm 0.44^{\mathrm{c}}$ \\
$2: 00$ & $60.71 \pm 0.24^{\mathrm{c}}$ \\
$2: 30$ & $60.84 \pm 0.21^{\mathrm{c}}$ \\
$3: 00$ & $62.43 \pm 0.91^{\mathrm{b}}$ \\
$3: 30$ & $64.34 \pm 0.47^{\mathrm{a}}$ \\
$4: 00$ & $64.20 \pm 0.42^{\mathrm{a}}$ \\
$4: 30$ & $65.44 \pm 1.10^{\mathrm{a}}$ \\
\hline
\end{tabular}

Results shown were means \pm S.D. in triplicate $(n=3)$. ${ }^{\text {a-e }}$ Mean with different letters indicate significant difference $(p<0.05)$

Figure 2 shows Brix measurement of UHT milk with 30 min time interval. It was found that the Brix values of UHT milk and control sample was significant $(p<0.05)$. However, Brix values of UHT milk were constant throughout the experiment. Hence, it could be assumed that there were no changes of total solids in UHT milk.

Next, Figure 3 shows the results for colour measurement in terms of lightness (L*) of UHT milk with 30 min time interval. The lightness of fresh UHT milk was increasing significantly across time except at time 2:30 and 3:00 $(p>0.05)$ and all $\mathrm{L}^{*}$ values of fresh milk were significant with control sample which had the lowest $L^{*}$ value $(p<0.05)$. The results for colour measurement in terms of 


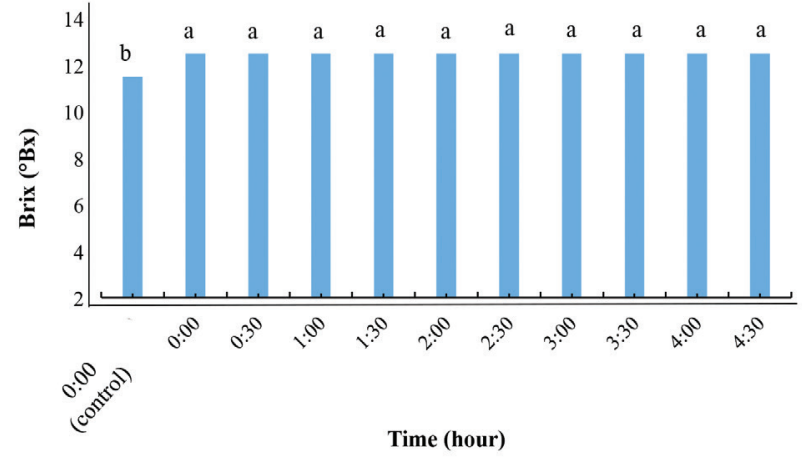

FIGURE 2. Brix measurement of UHT milk with $30 \mathrm{~min}$ time interval. Results shown were means \pm S.D. in triplicate $(n=3)$. ${ }^{\mathrm{a}-\mathrm{b}}$ Mean with different letters indicate significant difference $(p<0.05)$

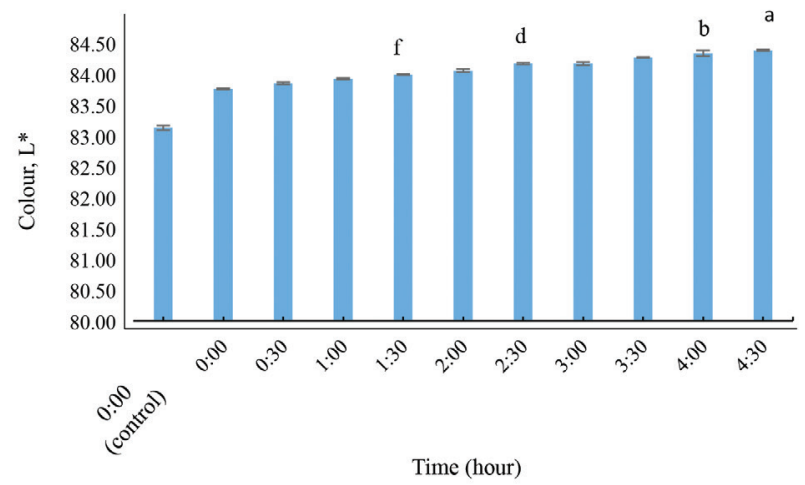

FIGURE 3. Colour ( $\left.\mathrm{L}^{*}\right)$ measurement of UHT milk with $30 \mathrm{~min}$ time interval. Results shown were means \pm S.D. in triplicate $(n=3) .{ }^{a-j}$ Mean with different letters indicate significant difference $(p<0.05)$

yellow intensity are shown in Figure 4. It was found that the yellow intensity of fresh UHT milk at all times were significant with control sample $(p<0.05)$. The $b^{*}$ values of fresh milk kept increasing until 2:30 and it began to decrease at 3:00 and 3:30 significantly $(p<0.05)$, though the $b^{*}$ values were found to increase again at 4:00 till the end of experiment. Kneifel et al. (1992) stated that an increase in psychometric chrome (b*) can be as an indicator for milk spoilage during storage, especially spoilage which is not caused by enzyme. This kind of spoilage is known as Maillard reaction.

Figure 5 shows the $\mathrm{pH}$ values of fresh UHT milk with 30 min time interval and it was found that the $\mathrm{pH}$ of fresh milk at the beginning of the experiment, 0:00 was the lowest and not only significant with $\mathrm{pH}$ of fresh milk at other times, but also with control sample $(p<0.05)$. Overall, $\mathrm{pH}$ readings of fresh milk kept fluctuating throughout the experiment. A decrease of $\mathrm{pH}$ was found at 2:00 and 4:30. According to Berg and van Boekel (1994), a decrease in $\mathrm{pH}$ may happen due to Maillard reaction due to formation of formic acid during intermediate stage. However, as stated by Sunds et al. (2017), intermediate stage of Maillard reaction requires high temperature like $40-50^{\circ} \mathrm{C}$ to occur. This study was only done at room temperature which was $27 \pm 0.3^{\circ} \mathrm{C}$.

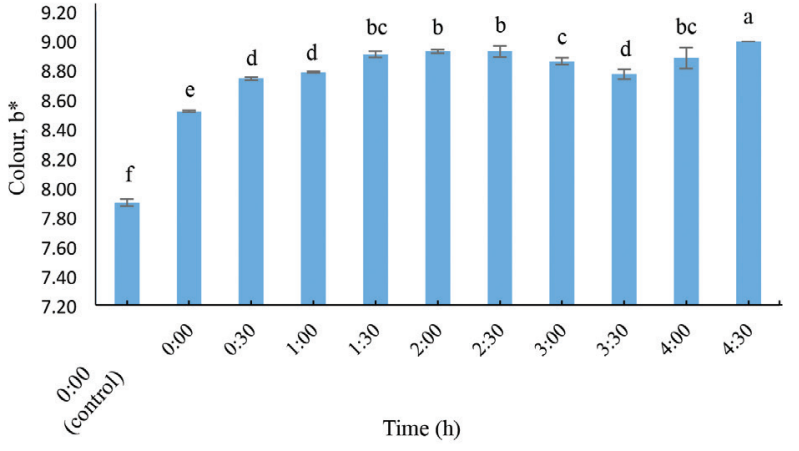

FIGURE 4. Colour ( $b^{*}$ ) measurement of UHT milk with 30 min time interval. Results shown were means \pm S.D. in triplicate $(n=3) .{ }^{\text {a-f }}$ Mean with different letters indicate significant difference $(p<0.05)$

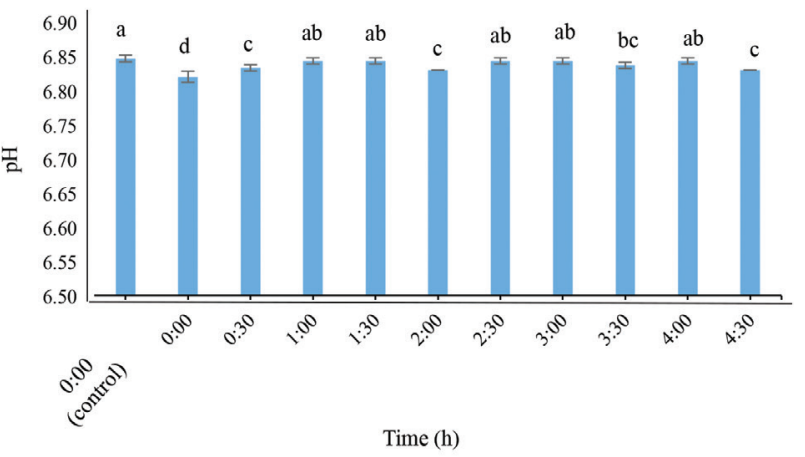

FIGURE 5. $\mathrm{pH}$ measurement of UHT milk with 30 min time interval. Results shown were means \pm S.D. in triplicate $(n=3) .{ }^{\text {a-c }}$ Mean with different letters indicate significant difference $(p<0.05)$

The results for microbiological analysis are shown in Table 4. Based on the analysis, the presence of microorganisms in milk sample was detected only at $3: 30$ and increased significantly till the end of experiment $(p<0.05)$. That means the high value of contact angle at 1:30 was not caused by presence of microorganisms in milk sample. Based on those past studies by Handojo et al. (2009) and Michalski et al. (1997), it could be concluded that the attraction between milk droplets and the surface of PLLA film decreased over time. On the contrary, the intermolecular forces in milk increased over time. At 1:30 and above, the intermolecular forces in milk started to exceed the strength of attraction between milk droplets and surface of PLLA film. This situation had caused the milk droplets on PLLA film to become more rounded on the surface, hence causing the contact angle to increase. Meanwhile, there was significant difference between contact angle of milk between before and after microorganisms were present. This proves that the presence of microorganisms also affected the values of contact angle of UHT milk on PLLA film. However, there was insignificant difference of contact angle of milk between 3:30 and 4:30 although colony forming unit of microorganisms in milk sample increased significantly 
TABLE 4. Microbiological analysis of UHT milk with 30 min time interval

\begin{tabular}{cc}
\hline Time $(\mathrm{h})$ & Colony count $(\mathrm{cfu} / \mathrm{mL})$ \\
\hline $0: 00-3: 00$ & $<1.0 \times 10^{0 \mathrm{a}}$ \\
$3: 30$ & $2.1 \times 10^{3 \mathrm{a}}$ \\
$4: 00$ & $3.0 \times 10^{4 \mathrm{~b}}$ \\
$4: 30$ & $3.9 \times 10^{4 \mathrm{c}}$ \\
\hline
\end{tabular}

Results shown were means \pm S.D. in triplicate $(n=3)$. $^{\text {a-c }}$ Mean with different letters indicate significant difference $(p<0.05)$

till the end of experiment. This shows that PLLA has the ability to detect the presence of microorganisms in milk, though it is less sensitive to colony forming unit of microorganisms.

In this study, as shown in Table 5, relationship between variables was also determined by using coefficient of determination, $\mathrm{R}^{2}$ and Pearson correlation, $r$. With these two regression analyses, the strength of relationship and correlation between contact angle and other variables (Brix, colour, $\mathrm{pH}$ and colony forming unit) can determined. Based on Table 5, the strength of relationship between contact angle and colony forming unit is the highest $\left(\mathrm{R}^{2}=0.341, \mathrm{r}=0.574\right) .34 \%$ of variance in contact angle was explained by colony forming unit and since its Pearson's $r$ is quite close to 1 , it can be concluded that there is a strong relationship between these two variables. This means that changes in colony forming unit are strongly correlated with changes in contact angle. The second variable which has strong relationship with contact angle is colour $\left(\mathrm{L}^{*}\right)\left(\mathrm{R}^{2}=0.3293, r=0.566\right)$, followed by colour $\left(\mathrm{b}^{*}\right)\left(\mathrm{R}^{2}=0.1137, r=0.331\right), \mathrm{pH}\left(\mathrm{R}^{2}\right.$ $=0.1122, r=0.294)$ and Brix $\left(\mathrm{R}^{2}=0.0014, r=0.036\right)$. Pearson's $r$ for relationship between Brix and contact angle is close to 0 , hence it can be concluded that there is a weak relationship between these two variables. Overall, Pearson's $r$ for all relationship is positive which indicates positive relationship (Fazil et al. 2016). As one variable increases in value, the second variable also increases in value.

The wettability analysis of the contaminated milk on PLLA thin film and indicator of contamination by microorganisms in UHT milk are shown in Table 6 and Figure 6A, respectively. The images of milk droplets on PLLA film at 0:00 and 3:30 as well as the contaminated milk are shown in Figure 6B(i), Figure 6B(ii) and Figure 6B(iii), respectively.

\section{CONCLUSION}

The presence of microorganisms in UHT milk had caused a few physicochemical changes in the milk which were an increase in lightness, a decrease in yellow intensity and an increase in contact angle significantly. Colony forming unit of microorganisms with 30 min time interval had been studied. Presence of microorganisms in milk happened after the milk was unsealed and exposed to environment with temperature $27 \pm 0.3^{\circ} \mathrm{C}$ and relative humidity as much as $73 \pm 1 \%$ for $3 \mathrm{~h}$ and $30 \mathrm{~min}$. The colony forming unit of microorganisms at that time was $2.1 \mathrm{cfu} / \mathrm{mL}$ and increased significantly across time. The relationship between wetting of thin film PLLA and colony forming unit of microorganisms had been studied as well. The presence of microorganisms in milk at 3:30 with its colony forming unit, $2.1 \mathrm{cfu} / \mathrm{mL}$ had caused the contact angle of milk on PLLA film to be $64.34^{\circ}$. Based on regression analyses, colony forming unit of microorganisms is correlated to contact angle. However, it was found that there was no significant difference of contact angle from 3:30 till 4:30 although the colony forming unit of microorganisms in milk was found to be increased significantly across those times. This shows that PLLA was less sensitive to colony count of microorganisms. As a conclusion, PLLA thin film can be used to detect the presence of microorganisms in UHT milk product, though it is less sensitive to the colony count of the microorganisms.

TABLE 5. Coefficient of determination and Pearson correlation on strength of relationship between Brix, colour $\left(\mathrm{L}^{*}\right)$, colour $\left(\mathrm{b}^{*}\right)$, $\mathrm{pH}$, colony forming unit of microorganisms and contact angle

\begin{tabular}{lcccccc}
\hline & & Brix & Colour $\left(\mathrm{L}^{*}\right)$ & Colour $\left(\mathrm{b}^{*}\right)$ & $\mathrm{pH}$ & Colony forming unit \\
\hline Coefficient of determination, $\mathrm{R}^{2}$ & Contact angle & 0.001 & 0.33 & 0.11 & 0.11 & 0.34 \\
\hline Pearson correlation, $\mathrm{r}$ & Contact angle & 0.036 & 0.57 & 0.33 & 0.30 & 0.62 \\
\hline
\end{tabular}

TABLE 6. Contact angle, output and wetting of UHT milk on PLLA film

\begin{tabular}{cccccccc}
\hline \multirow{2}{*}{ Time (h) } & \multicolumn{9}{c}{ Output } & \multicolumn{2}{c}{ Range of contact } \\
\cline { 2 - 7 } & $\begin{array}{c}\text { Range of }(\theta) \\
\text { Brix }\left({ }^{\circ} \mathrm{Bx}\right)\end{array}$ & $\begin{array}{c}\text { Range of } \\
\text { colour }\left(\mathrm{L}^{*}\right)\end{array}$ & $\begin{array}{c}\text { Range of } \\
\text { colour }\left(\mathrm{b}^{*}\right)\end{array}$ & $\begin{array}{c}\text { Range of } \\
\mathrm{pH}\end{array}$ & $\begin{array}{c}\text { Colony count } \\
(\mathrm{cfu} / \mathrm{mL})\end{array}$ & $\begin{array}{c}\text { Diameter of } \\
\text { circle indicator } \\
(\mathrm{cm})\end{array}$ \\
\hline $0: 00-3: 00$ & $53.19-62.43^{\circ}$ & 12.5 & $83.76-84.17$ & $8.52-8.92$ & $6.82-6.84$ & $<1.0 \times 10^{0}$ & $0.7 \pm 0.05^{\mathrm{a}}$ \\
$3: 30-4: 30$ & $64.34-65.44^{\circ}$ & 12.5 & $84.27-84.39$ & $8.77-8.99$ & $6.83-6.84$ & $2.1 \times 10^{3}-3.9 \times 10^{4}$ & $0.5 \pm 0.05^{\mathrm{b}}$ \\
\hline
\end{tabular}




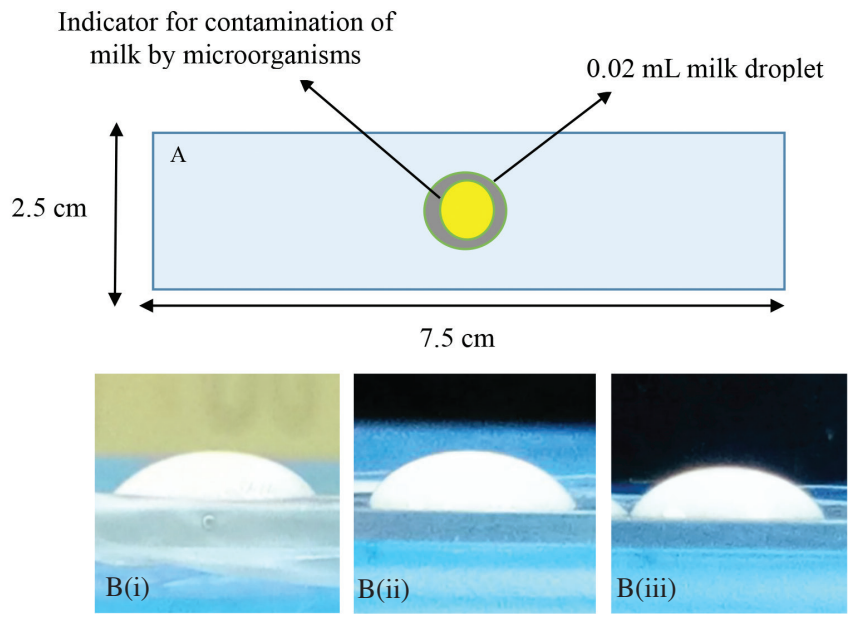

FIGURE 6. A) Indicator of contamination in UHT milk based on PLLA polymer thin film. B) Fresh UHT milk droplet on PLLA film at: i) time 0:00 with its contact angle, $50.70^{\circ}$; ii) time $3: 30$ with its contact angle, $64.20^{\circ}$; iii) its contact angle, $60 \cdot 30^{\circ}$. Contact angle was obtained using simplified experimental setup

\section{ACKNOWLEDGEMENTS}

All thanks are due to the Centre for Biotechnology \& Functional Food, Universiti Kebangsaan Malaysia (UKM) and Smart Material \& Food Engineering Group (SMAFEG) for the financial assistance providing the research facilities throughout the study.

\section{REFERENCES}

Ab Kadir, I.A., Jurid, S. \& Zubairi, S.I. 2016. Recycled palm oil spoilage: Correlation between physicochemical properties and oleophilicity. AIP Conf. Proc. 1784, 030004. http://aip. scitation.org/doi/abs/10.1063/1.4966742.

Ab Kadir, I.A., Jurid, L.S. \& Zubairi. S.I. 2017. Physicochemical properties of recycled refined, bleached and deodorized (RBDPO) palm olein: Which cycle should the olein considered spoilage? Jurnal Teknologi (Sciences and Engineering) 79(4): 17-25.

Berg, H.E. \& van Boekel, M.A.J.S. 1994. Degradation of lactose during heating of milk. 1. Reaction pathways. Netherlands Milk and Dairy Journal 48: 157-175.

Che Johari, N.S., Aizad, A. \& Zubairi, S.I. 2017. Efficacy study of carrageenan as an alternative infused material (filler) in poly(3-hydroxybutyrate-co-3-hydroxyvalerate) (PHBV) porous 3-D scaffold. International Journal of Polymer Science 2017: Article ID 5029194.

Cox, N.A., Bailey, J.S., Fung, D.Y.C. \& Hartman, P.A. 1987. Rapid methods for the detection and identification of microorganisms in food. In Food Protection Technology, edited by Felix, C.W. Michigan: Lewis Publishers, Inc. pp. 125-130.

Coyle, M.B. 2005. Manual of Antimicrobial Susceptibility Testing. United States: American Society for Microbiology.

Fazil, F.N.M., Azzimia, N.S.M., Yahaya, B.H., Kamalaldin, N.A. \& Zubairi, S.I. 2016. Kinetics extraction modelling and antiproliferative activity of Clinacanthus nutans water extract. The Scientific World Journal 2016: Article ID. 7370536.

Forschino, R., Ggaill, A. \& Ottogalli, G. 1990. Research on the microflora of UHT milk. Annali di Microbiologia ed Enzymologia 40: 47-59.
Handojo, A., Zhai, Y., Frankel, G. \& Pascall, M.A. 2009. Measurement of adhesion strengths between various milk products on glass surfaces using contact angle measurement and atomic force microscopy. Journal of Food Engineering 92(3): 305-311.

Ili Afiqa, A.K. 2017. Pembangunan penunjuk aras kerosakan minyak sawit olein terkitar semula. MS Thesis, Food Science Program, Universiti Kebangsaan Malaysia (Unpublished).

KKM. 2012. Laporan Tahunan Bahagian Keselamatan Dan Kualiti Makanan 2011: Program Susu 1Malaysia (PS1M). Putrajaya: Kementerian Kesihatan Malaysia.

Kneifel, W., Ulberth, F. \& Schaffer, E. 1992. Tristimulus colour reflectance measurement of milk and dairy products. Le Lait 72(4): 383-391.

Krasowska, A. \& Sigler, K. 2014. How microorganisms use hydrophobicity and what does this mean for human needs? Frontiers in Cellular and Infection Microbiology. https://doi. org/10.3389/fcimb.2014.00112.

Luck, H., Mostert, J.F. \& Husmann, R.A. 1978. Bacteriological evaluation of UHT milk. South African Journal of Dairy Technology 10: 83-85.

Malaysia. 2015. Food Act 1983 (Akta 281). (Regulation 82 \& 87).

Michalski, M.C., Desobry, S. \& Hardy, J. 1997. Food materials adhesion: A review. Critical Reviews in Food Science and Nutrition 37(7): 591-619.

Ramlan, N., Zamri, N.W.M., Maskat, M.Y., Aizad, S. \& Zubairi, S.I. 2018. Effect of plasma treatment $\left(\mathrm{He} / \mathrm{CH}_{4}\right)$ on the glass surface during drying to reduce powder flux adhesion. Sains Malaysiana 47(6): 1147-1155.

Ramlan, N., Zamri, N.W.M., Maskat, M.Y. \& Zubairi, S.I. 2017. Effects of chemical surface coating (rain-ZTM) on the powder yield of spray-drying: A preliminary approach. Acta Horticulture 1152(23): 165-174.

Skladal, P., Mascini, M., Salvadori, C. \& Zannoni, G. 1993. Detection of bacterial contamination in sterile UHT milk using an L-lactate biosensor. Enzyme \& Microbial Technology 15(6): 508-512.

Sousa, C., Rodrigues, D., Oliveira, R., Song, W., Mano, J.F. \& Azeredo, J. 2011. Superhydrophobic poly(L-lactic acid) surface as potential bacterial colonization substrate. $A M B$ Express 1(1): 34-42. 
Sunds, A.V., Rauh, V.M., Sørensen, J. \& Larsen, L.B. 2017. Maillard reaction progress in UHT milk during storage at different temperature levels and cycles. International Dairy Journal 77: 56-64.

Tamime, A.Y. 2009. Milk Processing and Quality Management. Oxford: Blackwell Publishing Ltd.

Tsuji, H. \& Ikada, Y. 1988. Blends of aliphatic polysters II. Hydrolysis of soution-cast blends from poly(L-lactide) and poly(E-caprolactone) in phosphate-buffered solution. Journal of Applied Polymer Science 67(3): 405-415.

Wang, Y. \& Salazar, J.K. 2015. Culture-independent rapid detection methods for bacterial pathogens and toxins in food matrices. Comprehensive Reviews in Food Science and Food Safety 15(1): 183-205.

Yusmawati, M.Y. 2011. Susu Coklat ada Bakteria. myMetro. http://cintaiindah.blogspot.my/2011/07/adakah-undang2kita-gubal-lebih-baik.html. Accessed on 30 April 2017.

Zubairi, S.I., Mantalaris, A., Bismarck, A. \& Aizad, S. 2016. Polyhydroxyalkanoates (PHAs) for tissue engineering applications: Biotransformation of palm oil mill effluent (pome) to value-added polymers. Jurnal Teknologi (Sciences and Engineering) 78(1): 13-29.

Zubairi, S.I., Bismarck, A. \& Mantalaris, A. 2015a. The effect of surface heterogeneity on wettability of porous three dimensional (3-D) scaffolds of poly(3-hydroxybutyric acid) (PHB) and poly(3-hydroxybutyric-co-3-hydroxyvaleric acid) (PHBV). Jurnal Teknologi (Sciences and Engineering) 75(1): 305-312.
Zubairi, S.I., Mantalaris, A. \& Bismarck, A. 2015b. A rapid approach to the pore interconnectivity analysis of porous three dimensional scaffolds of poly(3-hydroxybutyric acid) (PHB) and poly(3-hydroxybutyric-co-3-hydroxyvaleric acid) (PHBV) through non-invasive color staining method. Sains Malaysiana 44(9): 1531-1356.

Centre for Biotechnology \& Functional Food

Faculty of Science and Technology

Universiti Kebangsaan Malaysia

43600 UKM Bangi, Selangor Darul Ehsan Malaysia

*Corresponding author; email: saiful-z@ukm.edu.my

Received: 9 February 2018

Accepted: 17 July 2018 